\title{
A Study on Cementation Process of Lead from Brine Leaching Solution by Aluminum Powder
}

\author{
P. Abdollahi', H. Yoozbashizadeh1, D. Moradkhani², D. Behnian² \\ ${ }^{1}$ Materials Science and Engineering Department, Sharif University of Technology, Tehran, Iran \\ ${ }^{2} \mathrm{R}$ \& D Center, IZMDC Company, Tehran, Iran \\ Email: pa_abdollahi@yahoo.com,yoozbashi@sharif.edu
}

Received 6 February 2015; accepted 22 February 2015; published 28 February 2015

Copyright (C) 2015 by authors and OALib.

This work is licensed under the Creative Commons Attribution International License (CC BY).

http://creativecommons.org/licenses/by/4.0/

(c) (i) Open Access

\section{Abstract}

Hydrometallurgical recycling of lead from zinc plant residue which occurs at leaching plant has been investigated. After determination of optimum parameters in the brine leaching stage, the pregnant solution was proposed on cementation process by Aluminum powder and parameters (time, temperature, initial $\mathrm{pH}$ of solution, initial lead content of solution, $\mathrm{Al}: \mathrm{Pb}$ fraction, stirring velocity) were investigated and optimized.

\section{Keywords}

Lead Recovery, Brine Leaching, Cementation, Aluminum Powder

Subject Areas: Material Experiment, Metal Material

\section{Introduction}

Lead is commonly produced by pyrometallurgical techniques involving considerable environmental pollution. Pollution control can be improved by combined hydrometallurgical routes through implementation of closed loop operations. Increasing demand for copper, lead and zinc has led to worldwide efforts for utilization of low and off-grade ores of the above metals. One such ore is the zinc plant residue which cannot be treated economically by conventional pyrometallurgical techniques because of difficulties associated in producing individual concentrates from the ore [1] [2].

During the conventional zinc hydrometallurgical roast-leach-electro win process, lead and silver are reported in the neutral leach residue. Lead concentrates in the form of $\mathrm{PbSO}_{4}$ in the residue [1].

Besides the alkaline and acid extraction techniques mentioned above, some pyrometallurgical recovery processes and chloride leaching processes have been employed [3]-[7]. 
Lead sulphate can be converted to lead hydroxide by leaching with sodium hydroxide or lead carbonate with sodium carbonate [8].

$$
\mathrm{PbSO}_{4}+\mathrm{Na}_{2} \mathrm{CO}_{3}=\mathrm{PbCO}_{3}+\mathrm{Na}_{2} \mathrm{SO}_{4}
$$

These two products are not suitable for charging into the sinter machine due to their exothermic reaction during sintering. High cost of sodium hydroxide and sodium carbonate makes these routes unattractive [9].

Because of the availability of improved corrosion resistant materials of construction, considerable efforts have been made to develop chloride routes for lead production as alternatives to existing methods.

Using either $\mathrm{NaCl}$ or $\mathrm{MgCl}_{2}$ or $\mathrm{FeCl}_{3}$ for brine leaching has been reported [10].

Lead can be recovered by electrolyze of brine solution. It should be mentioned to crystallization and production of lead chloride and reduction by hydrogen can lead to production of lead [10] [12].

Zinc, iron or aluminum can be used to cement out lead and silver from the brine leach solution. It has been found that the process of cementation was slow in the case of zinc and iron whereas the aluminum was fast. So, aluminum has been used to cement out lead from the brine leach solution [10].

In cementation reactions, a metal in solution is reduced at the surface of a less noble substrate metal which dissolves anodically. These reactions are electrochemical in nature similar to those occurring in electrochemical corrosion processes. The half cell reactions and reduction potentials for lead and aluminum are as follows [13] [14]:

$$
\begin{array}{ll}
\mathrm{Al}^{3+}+3 \mathrm{e}=\mathrm{Al} & \mathrm{E}_{0}=-1.66 \mathrm{~V} \\
\mathrm{~Pb}^{2+}+2 \mathrm{e}=\mathrm{Pb} & \mathrm{E}_{0}=-0.126 \mathrm{~V} \\
\mathrm{~Pb}^{2+}+\mathrm{Al}=\mathrm{Al}^{3+}+\mathrm{Pb} &
\end{array}
$$

The overall reaction $\mathrm{Pb}^{2+}+\mathrm{Al}=\mathrm{Al}^{3+}+\mathrm{Pb}$ results from subtraction of Equation (2) from (3) and $\Delta \mathrm{E}_{0}=-0.126$ $\mathrm{V}-(-1.66 \mathrm{~V})=1.534 \mathrm{~V}$.

\section{Experimental}

\subsection{Materials}

Zinc plant residue of National Iranian Lead and Zinc Co.'s (NILZ) after brine leaching and water washing was used for all tests. The metal contents of feed were determined by using an Atomic Absorption Spectrometer (Perkin-Elmer, 300). The leachates were acidified with nitric acid to prevent precipitation of metals. Merk hydrochloric acid was used to acidify the brine solution. In cementation stage, aluminum powder with $99.5 \%$ purity was used.

\subsection{Experimental}

All the tests were carried out in the $1 \mathrm{~L}$ glass beakers to optimize the parameters. The plastic material shaft was used to avoid cementation of lead. To prevent evaporation during the tests, top of the beakers was covered. All solutions for cementation were obtained by leaching of secondary zinc plant residue (obtained after filtration of acid leaching and water washing of zinc plant residue) in the $300 \mathrm{~g} / \mathrm{L} \mathrm{NaCl}$ brine solution at time 30 min and temperature $30^{\circ} \mathrm{C}$. Aluminum powder was added suddenly to the solution and the effects of cementation temperature $\left(40^{\circ} \mathrm{C}, 50^{\circ} \mathrm{C}, 60^{\circ} \mathrm{C}, 70^{\circ} \mathrm{C}\right)$, time of cementation $(10,20,30,40,60,90 \mathrm{~min})$, initial $\mathrm{pH}$ of solution $(1,3$, $4,5,6)$, aluminum content $(1,1.5$, 2 stoichiometry $\times \mathrm{Pb})$, stirring speed $(50,100,150 \mathrm{rpm})$ and initial lead content of brine solution $(5.63,11.77,16.36 \mathrm{~g} / \mathrm{l})$ were investigated.

\section{Results and Discussion}

Cementation recovery of lead in Equation (4) was determined as Equation (5) in each time of sampling.

$$
\begin{gathered}
3 \mathrm{PbCl}_{2}+2 \mathrm{Al}=2 \mathrm{AlCl}_{3}+3 \mathrm{~Pb} \\
\% \mathrm{Rc}=\left(\mathrm{M}_{\mathrm{o}}-\mathrm{M}\right) / \mathrm{M}_{\mathrm{o}} \times 100
\end{gathered}
$$

In Equation (5): 
Rc is the cementation efficiency.

$\mathrm{M}_{\mathrm{o}}$ is the initial lead content at $\mathrm{t}=0$.

$\mathrm{M}$ is the lead content of solution in specified time.

Product of cementation is in the spongy form and during cementation floats at the top of the beaker.

\subsection{The Effect of Aluminum Adding on the Cementation Recovery}

The results of aluminum addition at the initial $\mathrm{pH}=4$ on the lead recovery are shown in Figure 1 . With addition of aluminum powder, $\mathrm{pH}$ of solution decreases.

The results show that the rate of lead cementation increases with raising the amount of $\mathrm{Al}$ at the same time and lead content of solution remained negligible after $90 \mathrm{~min}$.

According to Equation (4), increasing of aluminum causes reaction progress.

With addition of aluminum, contact surface reaction increases that leads to increasing of lead cementation.

\subsection{Effect of Temperature}

The results of increasing temperature on the recovery of lead are shown in Table 1 and Table 2.

The results show that increasing temperature has small effect on the lead recovery.

Small increase in the cementation recovery is because of increasing in the diffusion of reduced metal on the formed film of oxidized metal surface (Table 1, Table 2).

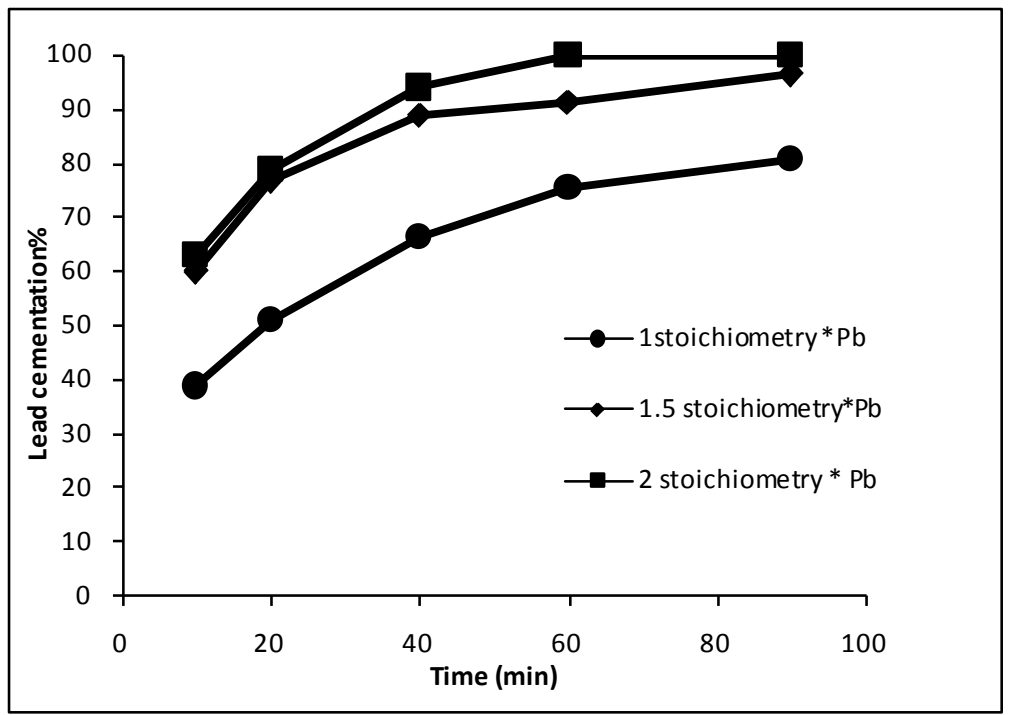

Figure 1. Effect of $\mathrm{Al}$ addition on lead cementation, $\mathrm{T}=50^{\circ} \mathrm{C}, \mathrm{pH}_{\text {in }}=4$, Stirring Velocity $=100 \mathrm{rpm}$.

Table 1. Effect of temperature on the cementation rate at $\mathrm{pH}_{\mathrm{in}}=4$, Stirring Velocity $=100 \mathrm{rpm}, \mathrm{Al}: \mathrm{Pb}$ ratio $=$ 1.5 (stoichiometry).

\begin{tabular}{ccccc}
\hline & $\mathrm{T}=40^{\circ} \mathrm{C}$ & $\mathrm{T}=50^{\circ} \mathrm{C}$ & $\mathrm{T}=60^{\circ} \mathrm{C}$ & $\mathrm{T}=70^{\circ} \mathrm{C}$ \\
\hline Time (min) & Lead recovery $\%$ & Lead recovery $\%$ & Lead recovery $\%$ & Lead recovery $\%$ \\
\hline 10 & 59.59 & 62.51 & 64.41 & 77.11 \\
20 & 76.65 & 78.89 & 79.54 & - \\
30 & - & 84.7 & - & 93.27 \\
40 & 86.74 & 88.74 & 90.11 & 99.49 \\
90 & 96.76 & - & 96.28 & 99.89 \\
\hline
\end{tabular}




\subsection{Effect of Stirring Velocity}

Some exams were carried out to examine the effect of stirring velocity on the cementation of lead. Table 3 shows the effect of stirring velocity on the lead cementation at $\mathrm{T}=30^{\circ} \mathrm{C}$.

According to lead cementation by adding the aluminum powder, in fewer stirring velocity, the remained aluminum powders were surrounded by the precipitated lead particles, so contact surface decreases for the cementation reaction.

In high stirring velocity, according to Equation (6) oxygen leads to decrease in the cementation recovery (Table 3).

$$
\mathrm{Pb}+2 \mathrm{H}_{2}+1 / 2 \mathrm{O}_{2}=\mathrm{Pb}^{2+}+\mathrm{H}_{2} \mathrm{O}
$$

\subsection{Effect of Initial pH of Solution on the Recovery of Lead}

The results of initial $\mathrm{pH}$ of the solution before addition of Aluminum powder on the lead recovery are show in Table 4.

The results show that increasing of $\mathrm{pH}$ from 4 to 6 decreases the cementation efficiency.

Increasing initial $\mathrm{pH}$ of solution before cementation, causes in precipitation of some lead as hydroxide.

It should be mentioned that with increasing of initial $\mathrm{pH}$ of solution, some Aluminum precipitates as hydroxide without its roll in lead cementation.

At initial $\mathrm{pH}$ of the solution less than 4, cementation process delays because of releasing Hydrogen ion according to Equation (7).

$$
\mathrm{Pb}+2 \mathrm{H}^{+}=\mathrm{Pb}^{2+}+\mathrm{H}_{2}
$$

As increasing of lead content in the solution, causes in reduction of hydrolyze $\mathrm{pH}$, cementation recovery reduces. By the way, it should be prevented of increasing $\mathrm{pH}$ before cementation (Table 4).

The results show low cementation recovery about a solution with initial $\mathrm{pH}=3$ in comparison with a solution with initial $\mathrm{pH}=4$.

Table 2. Effect of temperature on the cementation rate at $\mathrm{pH}_{\mathrm{in}}=1$, Stirring Velocity $=100 \mathrm{rpm}, \mathrm{Al}: \mathrm{Pb}$ ratio $=1.5$ (stoichiometry).

\begin{tabular}{ccc}
\hline & $\mathrm{T}=30^{\circ} \mathrm{C}$ & $\mathrm{T}=50^{\circ} \mathrm{C}$ \\
\hline Time (min) & Lead recovery $\%$ & Lead recovery $\%$ \\
\hline 10 & 52.58 & 54.11 \\
20 & 71.92 & 78.93 \\
40 & 94.98 & 97.03 \\
60 & 99.98 & 99.99 \\
\hline
\end{tabular}

Table 3. Effect of stirring velocity on the cementation rate at $\mathrm{T}=30^{\circ} \mathrm{C}$, Added Al: 1.5 (stoichiometry) $\times \mathrm{Pb}$.

\begin{tabular}{cccc}
\hline & $50 \mathrm{rpm}$ & $100 \mathrm{rpm}$ & $150 \mathrm{rpm}$ \\
\hline Time (min) & Lead recovery & Lead recovery & Lead recovery \\
\hline 10 & 37.11 & 52.58 & 41.11 \\
20 & 55.87 & 78.93 & 60.56 \\
40 & 78.54 & 97.03 & 78.82 \\
60 & 81.03 & 99.8 & 89.46 \\
\hline
\end{tabular}




\subsection{Effect of Initial Lead Content on the Cementation Recovery}

Some tests carried out to determine the initial lead content on the cementation recovery. So it was prepared some solutions with different initial lead content.

The results show that with increasing initial lead content, cementation recovery reduces.

According to Equation (8), increasing of lead content, increases driving force of cementation.

$$
\mathrm{Pb}^{2+}+2 \mathrm{e} \rightarrow \mathrm{Pb} \quad \mathrm{E}_{0}=-0.126 \quad \mathrm{E}=\mathrm{E}_{0}+\mathrm{RT} / \mathrm{ZFln}\left[\mathrm{Pb}^{2+}\right]
$$

Table 5 shows the initial lead content on the lead recovery.

Investigation by XRD shows Massicot $(\mathrm{PbO})$, Lead $(\mathrm{Pb})$, Halite $(\mathrm{NaCl})$, Litharge $(\mathrm{PbO})$ in the cementation product.

Table 6 shows chemical analyze results that the obtained product has a high purity and hence it can be used as Caldo furnace feed. Final product also is suitable because of its valuable elements such as Silver, Antimony.

\section{Conclusions}

The cementation of lead with aluminum powder was investigated. According to results, cementation with Aluminum is fast and economical. According to results, temperature has no more effect on cementation recovery. It is proved that rising of initial lead content, increases the recovery of cementation at the same times.

According to results, stoichiometric ratio $\mathrm{Al}: \mathrm{Pb}$ of 1.5 was found to be optimum for maximum lead recovery.

Table 4. Effect of initial $\mathrm{pH}$ of the solution on the cementation recovery $\left(\mathrm{T}=50^{\circ} \mathrm{C}\right.$, Stirring Velocity $=100 \mathrm{rpm}$, Added $\mathrm{Al}$ : 1.5 (stoichiometry) $\times \mathrm{Pb}$ ).

\begin{tabular}{ccccc}
\hline & $\mathrm{pH}=6$ & $\mathrm{pH}=5$ & $\mathrm{pH}=4$ & $\mathrm{pH}=3$ \\
\hline Time (min) & Lead recovery $\%$ & Lead recovery $\%$ & Lead recovery $\%$ & Lead recovery \% \\
\hline 10 & 44.39 & 48.52 & 53.24 & 47.53 \\
20 & 62.01 & 63.29 & 71.03 & 63.68 \\
30 & - & - & 78.79 & - \\
40 & 81.62 & 84.48 & 84.66 & -50 \\
60 & 95.54 & 96.89 & - & 94.06 \\
\hline
\end{tabular}

Table 5. Effect of initial lead content on the cementation recovery (Initial $\mathrm{pH}=4, \mathrm{~T}=40^{\circ} \mathrm{C}$, Stirring Velocity $=100 \mathrm{rpm}$, Added Al: 1.5 (stoichiometry) $\times \mathrm{Pb}$ ).

\begin{tabular}{cccc}
\hline Time (min) & Initial $\mathrm{pb}=5.63$ & Initial $\mathrm{pb}=11.77$ & Initial $\mathrm{pb}=16.36$ \\
\hline 10 & 46.18 & 55.39 & 59.597 \\
20 & 70.4 & 73.12 & 76.65 \\
40 & 90.48 & 89.87 & 94.12 \\
60 & 96.02 & 96.75 & 98.17 \\
\hline
\end{tabular}

Table 6. Chemical composition of precipitated product $\left(\mathrm{T}=30^{\circ} \mathrm{C}\right.$, Stirring Velocity $=50 \mathrm{rpm}$, Added Al: 1.5 (stoichiometry) $\times \mathrm{Pb})$.

\begin{tabular}{cccccccc}
\hline Element & $\mathrm{Pb}$ & $\mathrm{Ag}$ & $\mathrm{Al}$ & $\mathrm{Zn}$ & $\mathrm{Cd}$ & \\
\hline$\%$ & 76.94 & 0.12 & 2.49 & 0.087 & Trace \\
\hline
\end{tabular}




\section{Acknowledgements}

Writers would like to express their thanks to IZMDC for partial financial support of the project.

\section{References}

[1] Jha, M.K., Kumar, V. and Singh, R.J. (2001) Review of Hydrometallurgical Recovery of Zinc from Industrial Wastes. Resources, Conservation and Recycling, 33, 1-22. http://dx.doi.org/10.1016/S0921-3449(00)00095-1

[2] Rabah, M.A. and El-Sayed, A.S. (1995) Recovery of Zinc and Some of Its Valuable Salts from Secondary Resources and Wastes. Hydrometallurgy, 37, 23-32. http://dx.doi.org/10.1016/0304-386X(94)00015-U

[3] Wang, M.C. New Hydrometallurgical Process for Lead Production: Conversion-Flotation-Electrowinning (CFE) Process. Lead and Zinc, 80, 785-801.

[4] Jansz, J.J.C. Non-Oxidative Chloride Leaching of Complex Pyritic Zinc-Lead Sulphide Materials. Lead and Zinc, 90, 548-573.

[5] Sandberg, R.G. and Huiatt, J.L. (1986) Ferric Chloride, Thiourea and Brine Leach Recovery of Ag, Au and Pb from Complex Sulfides. Journal of Metals, 38, 18-22.

[6] Sinadinovic, D., Kamberovic, Z. and Sutic, A. (1997) Leaching Kinetics of Lead from Lead (II) Sulphate in Aqueous Calcium Chloride and Magnesium Chloride Solutions. Hydrometallurgy, 47, 137-147. http://dx.doi.org/10.1016/S0304-386X(97)00041-8

[7] Abdollahi, P., Moradkhani, D., Behnian, D. and Yozbashizadeh, H. (2006) Lead Recovery from Iranian Zinc Plant Residue Using Brine Leaching Method. Proceedings of XXII International Mineral Processing Congress, Istanbul, $1515-1520$.

[8] Arai, K. and Toguri, J.M. (1984) Leaching of Lead Sulphate in Sodium Carbonate Solution. Hydrometallurgy, 12, 4959. http://dx.doi.org/10.1016/0304-386X(84)90047-1

[9] Raghavan, R., Mohanan, P.K. and Swarnkar, S.R. (2000) Hydrometallurgcal Processing of Lead-Bearing Materials for the Recovery of Lead and Silver as Lead Concentrate and Lead Metal. Hydrometallurgy, 58, 103-116. http://dx.doi.org/10.1016/S0304-386X(00)00108-0

[10] Raghavan, R., Mohanan, P.K. and Patnaik, S.C. (1998) Innovative Processing Technique to Produce Zinc Concentrate from Zinc Leach Residue with Simultaneous Recovery of Lead and Silver. Hydrometallurgy, 48, 225-237. http://dx.doi.org/10.1016/S0304-386X(97)00082-0

[11] Turan, M.D., Altundogan, H.S. and Tumen, F. (2004) Recovery of Zinc and Lead from Zinc Plant Residue. Hydrometallurgy, 75, 169-176. http://dx.doi.org/10.1016/j.hydromet.2004.07.008

[12] Habashi, F. A Textbook of Hydrometallurgy.

[13] Sahoo, P.K. and Rath, P.C. (1988) Recovery of Lead from Complex Sulfide Leach Residue by Cementation with Iron. Hydrometallurgy, 167-177.

[14] Pourbaix, M. (1974) Atlas of Electrochemical Equilibrium in Aquaous Solutions. Houston. 
Scientific Research Publishing (SCIRP) is one of the largest Open Access journal publishers. It is currently publishing more than 200 open access, online, peer-reviewed journals covering a wide range of academic disciplines. SCIRP serves the worldwide academic communities and contributes to the progress and application of science with its publication.

Other selected journals from SCIRP are listed as below. Submit your manuscript to us via either submit@scirp.org or Online Submission Portal.
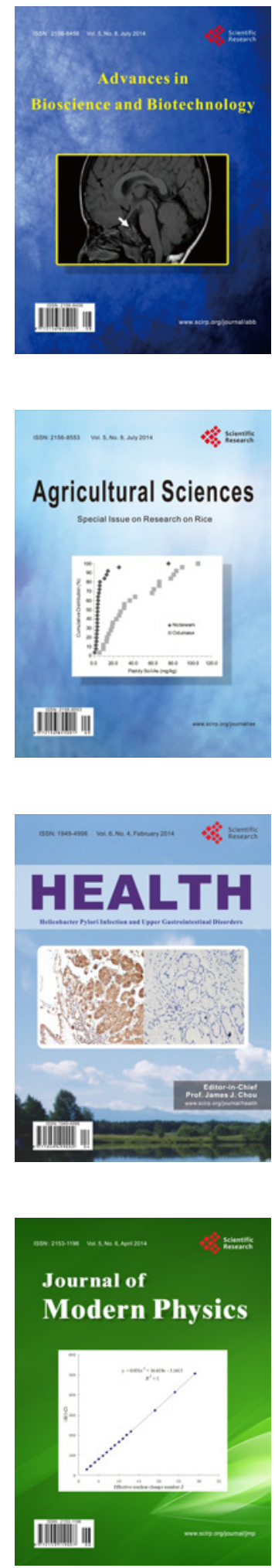
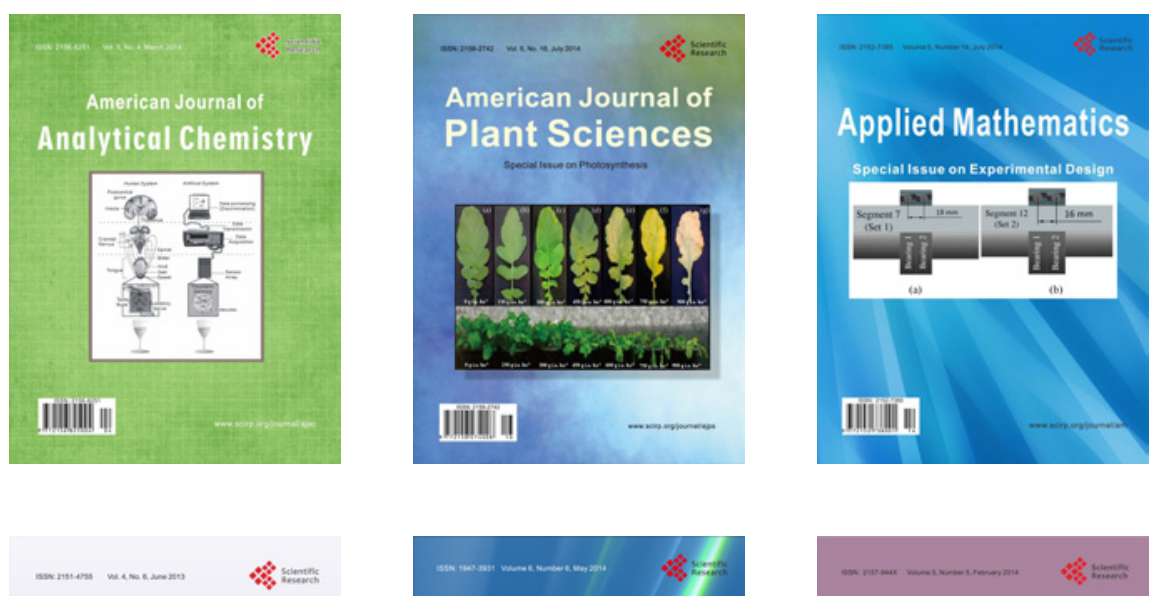

Creative Education
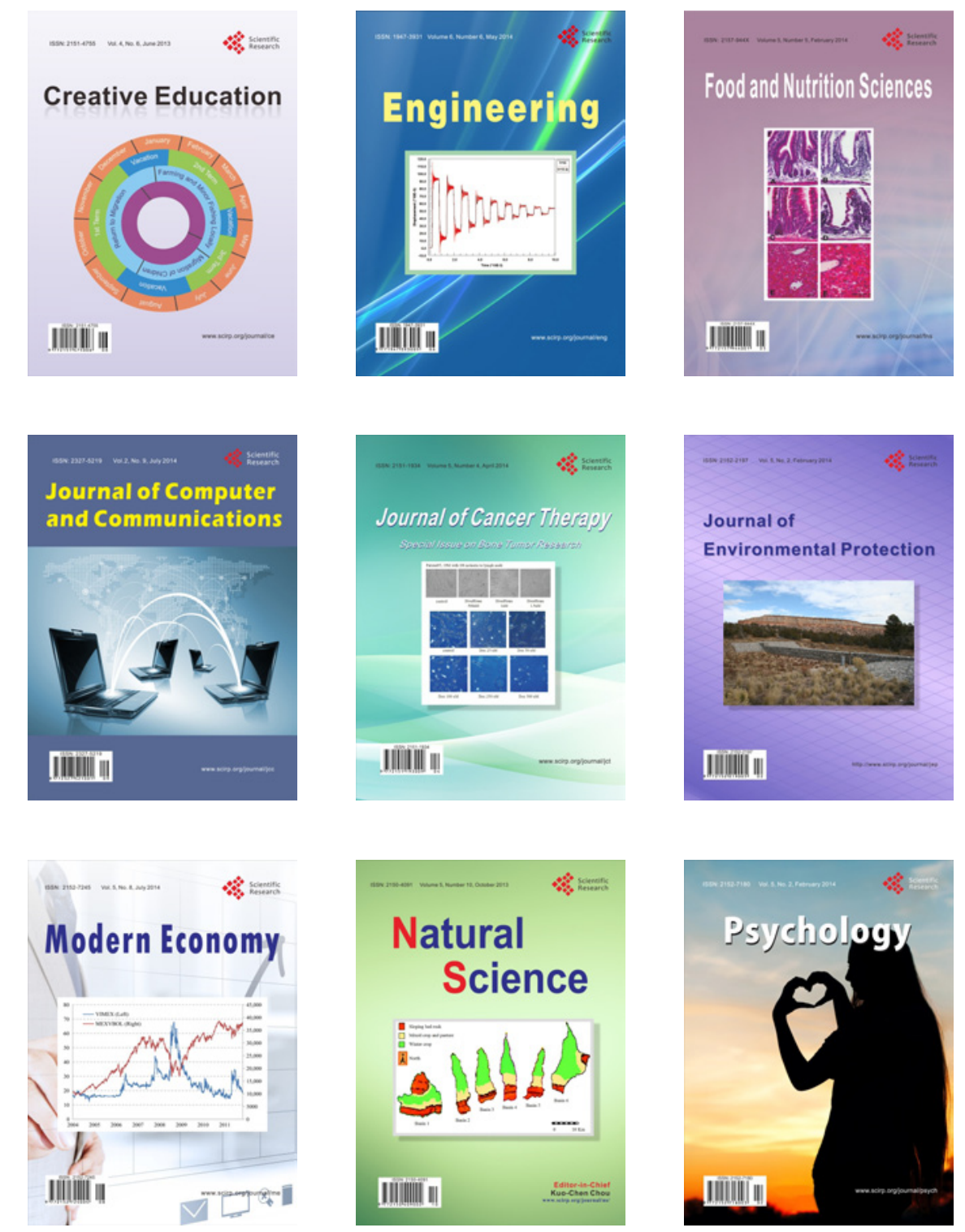